\title{
Correction to: Prognostic biomarkers related to breast cancer recurrence identified based on Logit model analysis
}

Xiaoying Zhou ${ }^{1 \dagger}$, Chuanguang Xiao ${ }^{2 \dagger}$, Tong Han ${ }^{3}$, Shusheng Qiu², Meng Wang ${ }^{2}$, Jun $\mathrm{Chu}^{2}$, Weike Sun ${ }^{2}$, Liang Li ${ }^{2}$ and Lili Lin ${ }^{4^{*}}$

\section{Correction to: World J Surg Onc 18, 254 (2020) \\ https://doi.org/10.1186/s12957-020-02026-z}

Following publication of the original article [1], the authors identified an error in the affiliation of Meng Wang and Jun Chu. Their institution should be " 2 Department of breast thyroid surgery, Central Hospital of Zibo, Zibo, 255036, Shandong, China".

The correct affiliation have been included in this correction. The authors apologize for this error.

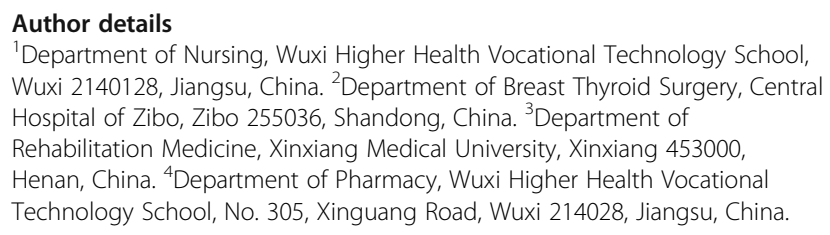

Published online: 05 December 2020

\section{Reference}

1. Zhou X, Xiao C, Han T, et al. Prognostic biomarkers related to breast cancer

recurrence identified based on Logit model analysis. World J Surg Onc.

2020;18:254. https://doi.org/10.1186/s12957-020-02026-z.

\footnotetext{
The original article can be found online at https://doi.org/10.1186/s12957020-02026-z.

* Correspondence: lyly567@sina.com

${ }^{+}$Xiaoying Zhou and Chuanguang Xiao contributed equally to this work.

${ }^{4}$ Department of Pharmacy, Wuxi Higher Health Vocational Technology

School, No. 305, Xinguang Road, Wuxi 214028, Jiangsu, China

Full list of author information is available at the end of the article
}

(C) The Author(s). 2020 Open Access This article is licensed under a Creative Commons Attribution 4.0 International License, which permits use, sharing, adaptation, distribution and reproduction in any medium or format, as long as you give appropriate credit to the original author(s) and the source, provide a link to the Creative Commons licence, and indicate if changes were made. The images or other third party material in this article are included in the article's Creative Commons licence, unless indicated otherwise in a credit line to the material. If material is not included in the article's Creative Commons licence and your intended use is not permitted by statutory regulation or exceeds the permitted use, you will need to obtain permission directly from the copyright holder. To view a copy of this licence, visit http://creativecommons.org/licenses/by/4.0/ The Creative Commons Public Domain Dedication waiver (http://creativecommons.org/publicdomain/zero/1.0/) applies to the data made available in this article, unless otherwise stated in a credit line to the data. 